\title{
犬の匂条件反射による嗅覚の研究
}

\author{
具瀬宏 \\ 群馬大学医学部第二生理学教室（主任 高木貞敬 教授）
}

実用面では, イヌはその卓越した嗅能力を利用さ れ，各国で警察犬として使用されている，例えばH. Kalmus （1957）は優秀でよく訓練されたイヌの追跡 実験で，一卵性双生児をも匂で識別し追跡することが できたと報告している。しかし目的物を探し持ってく る実験では，一卵性双生児の包をそれぞれ2枚のハン カチにつけ，家族抢よび他人の匂をつけたハンカチと 混ぜて置き，イ邓は双生㫛の一方の匂をかいでからそ の匂のするハンカチを持ってくるように命令される と, どちらか最初に出会った方の双生児のハンカチを 持ってきてしまう。

彼はこの両実験結果の差を実験状沉の差によるもの とし, 追跡実験では双生児両方の臭跡を同時にかぐこ とができ，後の実験では各ハンカチを次々とかぎ回 り，一つの匂にしか直面できなかったことにその原因 を求め, 後者の場合, かぎ覚光た包に充分似ていれば イ邓はとれを持ってきてしまうと報告している。そし て各個人間の匂の差は各種化学物質の混合の相違に基 づき，質的なものより量的なものではないかと述へて いる.

このように実用面に結びついた実験ではすぐれた報 告があるが、これらの識別能力を定量的に研究した報 告は少ない。

我が国では, イヌの感覚について条件反射による種 々の研究がなされているが，溴覚を扱ったものはな く，ただ分化形成に対する無条件刺激としての慨の包 の影響に関する知見があるに過ざない（深見1961）。 外国で嗅覚の条件反射を系統的に研究しはじめたの はW.F.Allen (1937〜1941) である。彼は一連の報 告の中で, 電気刺激を無条件刺激として clove oil を 陽性条件刺激（以後PCS と略す）とし， asafetidaを 陰性条件刺激（以後 NCS と略す）として前肢挙上反 応を起こすことに成功した。しかしこの研究には多く の問題点がある。たとえば clove oil に対する嗅覚閾 值には触れていないので恐らく高濃度の匂を使用した ものと思われる。またこの実験では口輪をはめたり，
また前肢を挙上したままのイヌでは後肢を持ち上げ柱 に結びつけ体重が前肢にかかるようにしたり，時には 条件反射（以後 $\mathrm{CR}$ と略す）の形成を早めるために薇 罰を与えたりして，イヌと人間の接触の機会が多くあ り，拘束も多すぎるという問題がある。

Becker, Markee and King (1957) は了種のT字型 問題箱を作りイイヌの clove oil 受容の閾值を求めた

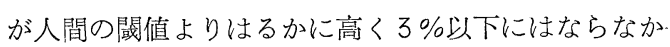
った。そのうえ，匂と一緒に与えた光刺激を除いた場 合, また実験者が解答を知らなかった場合には, イヌ の正解が偶発率に落ちたから, イヌが光や実験者から の情報に頼っていたことが明白である。また，彼らが 最も適当としている実験箱でも, イ邓にそこから脱出 しょうとする逃避反射が強く現われたということから わかるように, 彼らの実験装置にも問題があった。従 って彼らの失敗報告は実験環境を注意深くコントロー ルす心゙きことを教えている。

後年 Becker, King and Markee (1962) は前回の 失敗を正すために, Moulton, Ashton and Eayrs （1960）の装置と類似したものを作り，5個の匂の選 択部位を環状に作り，その中の一つにあらかじめ記憶 さ-せた匂物質を入れて, 当該臭の所で坐るようにイヌ を訓練した。匂の溶媒としては揮発性の ether を用 い, ether はまた NCS としても使用した. スライド グラスあるいは皿に滴下した包稀棌液の溶媒は烝発し たが，低濃度の場合匂物質 A, B（ある事情で物質名 を犁密にしている) の結晶中に浸透した ether が残 ってこの匂によってイヌが区別していた．そのため, ether に溶かした物質 $\mathrm{A} ， \mathrm{~B}$ をそれぞれ一方をPCS他 方を NCS とするようにしたが, 物質 A, B の対比法 で闒值を求めてゆく場合, 特に低濃度の場合は, たと えば $\mathrm{A}$ の閾值を求めるとき， $\mathrm{B}$ の匂のしない方をイヌ が選んでいる可能性もあった。また，溶質結晶中への アルコール吸収率等の問題もあって, 二種の匂を対比 してそれぞれの閾值を求めてゆく方法には問題が残さ れている。 
Moultonら (1960) は12フィート四方の部屋を観察 室, 実験室, イヌと訓練者の控室の三つに仕切り, 観 察者と訓練者の連絡は全てライト信号で行い訓練者に は解答を知らせなかった. 部屋の四隅にPotをおき 酸を入れたものと溶媒の蒸溜水だけを入れたものとを 設備して, 酸臭のある所で坐るょうに゙イヌを訓練し た.このようにして実験を行い，n-aliphatic acidの formic acid より caprylic acid までの8種につい て, イヌの匂識別能を炭素原子数に応じてプロットし 匂閾值を比較した。

その結果，炭素原子数が増えるにつれ閾值が対数的 に低くなってゆくのと，またC数の少ない最初の4つ のグループと後の 4 つのグループとの間に不連続性が あることを認めた．この二つのグループの間に存在す る唯一の物理化学的特徴は水溶性の違いであるから, この不連続性は鼻粘膜の水様成分に関連するものであ ろうと報告した。

また彼は，包に対する敏感さと，包をかき分けると いうことは異質のものであり，イヌが溴覚的にすぐれ た能力を持っているのは完全な嗅覚感受性を持ってい るというょりも, むしろその生活の必要性から発達し た匂をかぎ分ける能力によるものだと考えた。

W.Neuhaus (1953, 1955, 1956，1957) は, これ らの匂識別や追跡実験に詳細なデータを与え，その基 盤を打ち立てた。まず，Olfactometer を作り，包実 験台の三力所にあけた孔より空気，あるいは一定濃度 の実験臭を混じた空気を出せるようにセットした。各 孔の後に砂糖を入れた箱を置き，イヌが正確に実験臭 を選び出すと砂糖が与えられた。

この方法は溶媒中の匂物質濃度しか測定できなかっ た場合に比較し，実際に舅腔に入った空気中の匂濃度 を比較的㛜密に調節できる点ですぐれている。この装 置を使い，いくつかの匂物質の閾値を測定し，イヌの 嗅覚力は人間より 100万〜 1 億倍もすぐれていると報 告した。

彼はこれらの事実より，イヌの追跡実験のデータを 明快に説明した。すなわち，イヌは足の臭跡を頼りに 人間を追うことが既に確かめられているが，足からの 分泌物の量と質について詳細に検討した結果，24時間

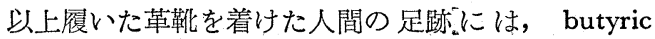
acid のような酸がイヌにとっては闖值の 100万倍以 上も残されており, 条件さえ良ければ，24時間以上も この匂の追跡が可能であると述べた．また彼は他の研
究により，イヌは特有なある一種の物質に頼ってその 人間をかぎ分けているのではなく，むしろ，閾值下の 量の匂をも含めて各物質が構成するパターンの相違, あるいは複合状態の差異によってかぎ分けていると結 論した。

闒值の測定は感覚研究のうえで重要な課題であり嗅 覚においてもその值が求められたが，現在まで行われ た研究では上記のごとく多くの複雑な要素が介入して いることがわかり，明確な結論が必ずしも得られてい ない.

著者は, 以上のような嗅覚閾值の研究の状況にかん がみて，イヌにとって生物学的意義のない包 clove oil (Sakae aromatic co Ltd) を用い，その機構が比 較的単純と考えられている，いわゆる classical conditioned reflexを代表する、睡液条件反射”を指標之 して, 嗅覚の閾値その他の解明を志し, 多少の知見を 得たのでここに報告する。

\section{実験․ 方 法}

実験にはイヌを用いた。本学動物舎に赴き多数のイ ヌの中から落着き, 聞き分け, 行儀の良さなどを基準 として24匹の雄イヌを選び，その中でさらに優れたイ ヌ13匹を選び出して耳下腺永久瘦の手術を施した。 それらのイヌを実験箱の中へ入れて餌の食べ方，恐怖 感, 音の条件反射の成立の有無を調べたところ, 条件 反射の実験に使用できると判断されたイ又は僅か3匹

$(\operatorname{Dog} 1, \operatorname{Dog} 2, \operatorname{Dog} 3)$ となった.

$\operatorname{Dog} 1$ は後で述べ一連の実験スケジュールを進め 包の分化条件反射が形成される頃から耳下腺瘦の周囲 に接着剤による接触性皮膚炎を生じ，更に化膿し，つ いに下顎全体にも及び唾液量測定が不可能となった。 また，Dog 2 は音条件反射で $500 \mathrm{c} / \mathrm{sec}$ の音に条件づ き，600c/sec，400c/sec をも分化し得たが，ついに 匂による条件反射を成立させることができなかった。

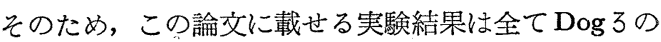
ものでDog $1, \operatorname{Dog} 2$ の実験結果は参考にとどめた。

(1) 実験装置

防音室内に奏験箱 $(68 \times 147 \times 78 \mathrm{~cm})$ を入れ図1の ごとく配置した．実験箱の一側はアクリル板で作られ ており，防音室の観測空から実験箱内が観察できるよ うになっている。しかしイヌには実験箱内より観察者 は見えないように工夫した。防音室内にさらに実験箱 をセットした主たる理由は脱臭を容易にするためであ 


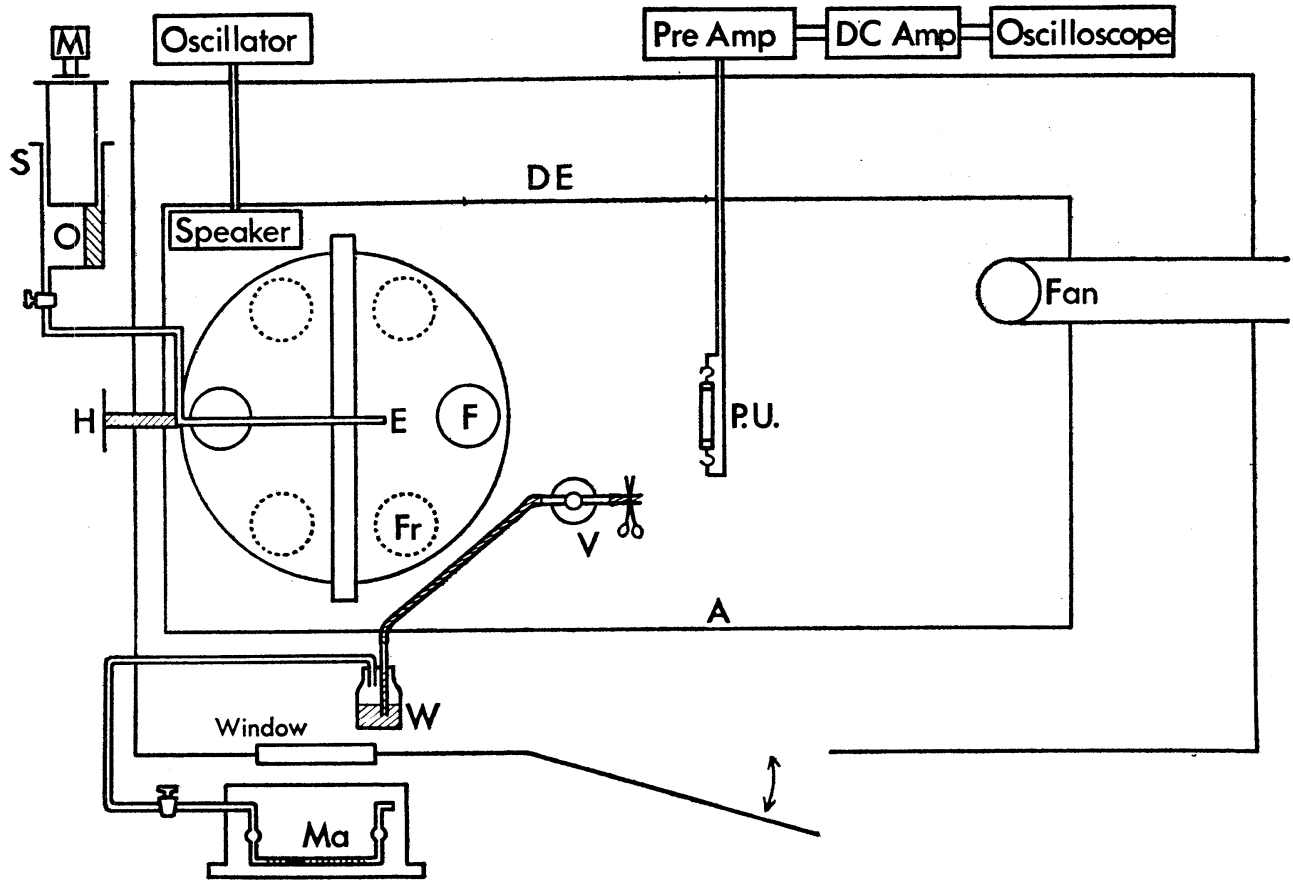

図1 実験装置

$\mathrm{A}$ ：アクリル面, DE：犬人川1, E : 匂出 I, Window：観測空

$\mathrm{F}$ ：飭血, Fan : 脱㚖扇, $\mathrm{H}$ ：ハンドル, $\mathrm{M}$ ：モーター

$\mathrm{Ma}_{\mathrm{a}}$ : 唾液測定マノメーター, O : 匂, P.U.：胸郭呼吸ピックアップ

$\mathrm{S}$ : 注射筒, $\mathrm{V} ：$ ヴァロンチカ

った。

食餌投与，刺激，記録などの実験操作はは全て防音室 外で行った。勿論，実験中トラブルがなければ人間は 防音室中に入らなかった。

脱臭扇は実験中常時作動させておいたが，その雑音 は音条件反射にも影響がなく，かえって防音室外の雑 音を打消し，実験箱内に人間が入ってみても外部の音 はほとんど聞こえなかった。

条件反射に用いた音は発振器より得られる発振波を スピーカーに導いて生じたものである。

匂刺激は匂物質（稀䣋した液 $1 \mathrm{cck}$ 空気 $29 \mathrm{cc}$ ) ある

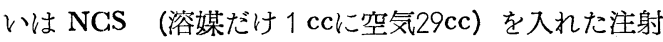
筒を細いテフロン管につなぎ，各々のチューブ末端匂 出口は図（E）の部位で餪皿より約 $15 \mathrm{~cm}$ 上の部位にあ る. 注射筒の内筒はモーターで作動し 1 秒間 $0.7 \mathrm{cc}$ の 一定速度で吹き出すようにした。これは噴出圧の差に よる分化をさけるためである。

睡液分泌量は唾液量測定マノメーター (目盛: $\mathrm{cm}$ )
の水の動きで読むことにより測定した。このマノメー ターは $1 \mathrm{cc}$ の睡液分泌量で $5.6 \mathrm{~cm}$ 移動する。また胸郭 呼吸ピックアップ（日本光電製）を装置し包刺激によ る呼吸変化を記録した。

実際に匂に触れる注射器，コネクター等の脱臭は， 溶媒だけで使用したものも全て同一条件で，同じ鍋に 入れ活性炭と中性洗剬を加えて煮沸し，その後水で充 分洗浄してからスチーム管上で乾燥した。また実験装 置は全て同一実験者が注意深く操作し, 実験臭以外の 匂がつかぬようにできるだけ細心な注意を払った。テ フロン管は匂物質の濃度を変える度にすべて新しく変 え，使用後のものは捨てた.

(2) 匂物質の稀哷

溶媒として匂の非常に稀薄な propylen glycol （小 宗化学 $\mathrm{KK}$, 東京) を使用した。低濃度の実験では, 一つの匂濃度を作るのに同じ鍋で煮沸，脱臭した 2 本 の稀积嚗を用意し，まず一本の嚗に propylen glycol （以後PG と略す）を入れ，これはNCSとして用い， 
そこから出した P G を他の嚗に入れた匂液の稀釈液と して使用し， clove oil を稀秎して PCS として用い た. clove oil (以後C.O.と略す) 以外の anise oil, eucalpitus oil, lavender oilをNCSとして与える場合 も气の稀釈はC.O.と同条件で行った。

(3) 実験スケシュュール

イヌの生活は, 午前10時から10時半頃まで散歩を行 い，食事は一日一回で午後 5 時頃に無条件刺激に使用 した飼料と異なる他の固型飼料を180〜200g与えた。

実験は午前11時より午後 3 時頃までの間に行い，実 験動物の drive の状態は慨の量, 実験時間 で調節し た.

イヌが実験箱中にいる時間は40～60分で，隔日に1 系列の実験を行い.1 系列の実験ではPCSを6回 (強化を含めて)，NCS は適宜無作為に加えた。ま た 1 系列の各条件刺激のPCS ・ NGSの順序之間隔（2 １5分）は共に篤作為に行い，時間条件反射等の形成 を避けた。

条件刺激に音, 匂のいずれを使用した場合も継時条 件反射で行い, 強化刺激では10秒間, GR をみる場合 には30秒間刺激してその間の唾液を測定し, 刺激終了 後直ちに固型飼料を 1 回に25g 与えた。この易合, 饂 の匂による影響を避けるため, PCS, NCS いずれ の場合にも図1（Fr）に慨を置いた。匂のNCSは通 常溶媒を用いたが，分化実験の初期には他の匂物質も 用いた。

$\mathrm{CR}$ の形成に当っては初めから条件刺激として匂だ けを与えたのでは CR 形成に成功しなかったが, 次の ような方法を用いると容易に CR 形成がみられた： (1)まず，音刺激で $\mathrm{CR}$ を完成させた。

(PCS 500c/sec, NCS 2000c/sec)

(2)次いで匂刺激のスイッチを押すと同特に瞬間的な white noise (以後WNと略す) が出るようにセット してWN+包 (30mgG.O. / cc) をPCSとし，NCSも 同様にWN+溶媒（PG）とした.

(3)上記実験で分化がみられるようになったら，直ちに WNを除き，包だけを刺激とする実験に移行した。

分化可能な閾值を求めるため, まず $30 m g$ C.O. $/ \mathrm{cc}$ による条件づけを形成して，次に溶媒または他の包と の分化実験を行い，次いで、C.O.濃度を薄め分化可能 な最低濃度を求めていった。
PCS として 500c/secを, NGS してて 2000c/secを 用いた実験で，分化形成は 8 系列目の実験で完成し た (図 2).

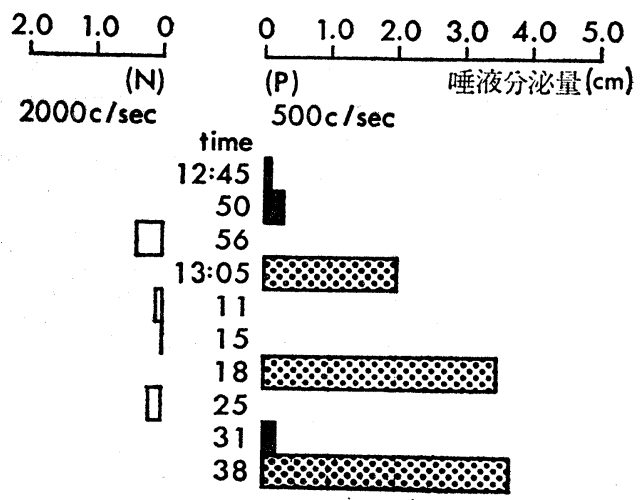

図 2 音条件汉射

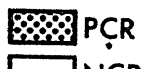

強化刺激(10秒間) 中の唾液望

以後図 2 のごとく陽性条件反射，陰性条件反射をそ れぞれPGR，NGRと略す。

（II）WNを合併させた包分化実験

この場合WNは各条件刺激（PCS，NCSに拘らず） の与兄られる最初の瞬間だけである。包刺激は30mg C.O. / ccがPCS，PGがNCSである.

最初の頃はイ又はWNに対する探求反射だけで，包 に気づいたような行動はなく CRの睡液量も增加しな かった。しかしイヌは実験箱内で静かにしていた。そ れ故，包刺激の存在を気づかせるために，NCS を時 に加えるだけで，7系列までほとんど強化刺激を与え た、そしてその頃になると，匂かぎ動作も確実に見ら

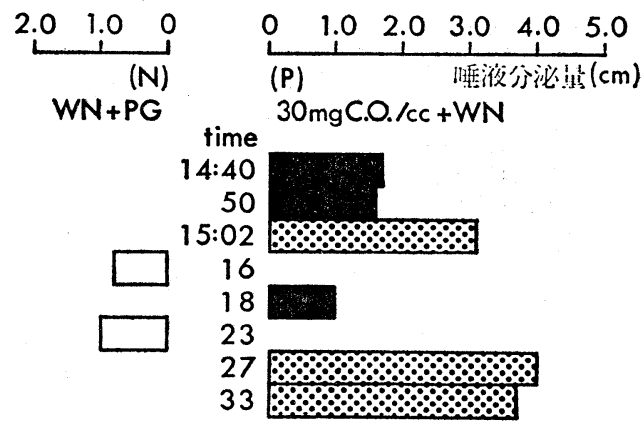

图3 WN+匂条俳文射

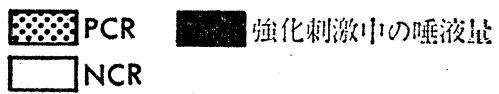


れるようになってきた。図了は9系列目の結果であ る.これでほほ包で分化することが明らかとなったの で，直ちにWN刺激を除いた包刺激害験に移った。

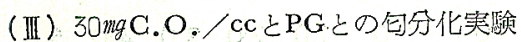

WN刺激を除去した初めの頃は，勿刺激を与えても 舅を匂出口に近づけないので，たまたま包出口に鼻を 近づけたときにPCS を与光ると，万系列目にPGRの 睡液量が3.2CMに上昇した。しかし，了系列までは鼻 を包出口近づける機会が少なく PCR \&少なかっ た。また，この段階ではNCSを続けて与えると，そ の後のPCRに抑制がみられた。

しかし 4, 5 系列以後性反応も安定し, 完全に分化 するようになった。

包だけの分化実験を始めてから 9.系列目に30mg Iavender oil /ccをNCSとして加えてみたが，最初から 30ng C.O. / $\mathrm{cc}$ と分化した。

更に30 ang anise oil /cc, 30 ing eucalpitus oil $/ \mathrm{cc}$ 加えていったが，いずれも初站から分化した。図 4 は 11系列目の結果で离る。

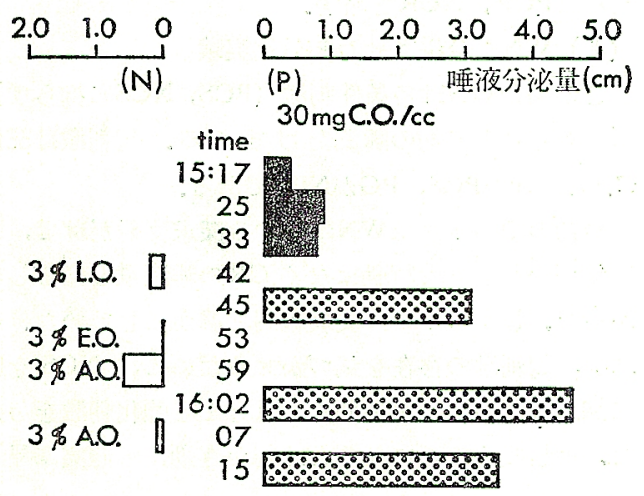

园4 他の创刺激との分化

OPCR
$\square$ NCR
L.O.: Lavender Oil E:O.: Eucalpitus Oil
A.O.: Anise Oil

匂分化が碓実になると，刺激を与えている間のイヌ の行動に違いが現わ机てきた。すなわち，図５はPCS を与えている時であるが，このように包出口と䬣皿の 間に鼻を入れ，そのまま静かに慨の与えられるのを待 っていた。NGS（図6）の場合は包いかかでいる

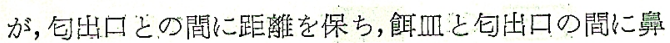
を入れることはなかった。しかし，分化不能時にここの

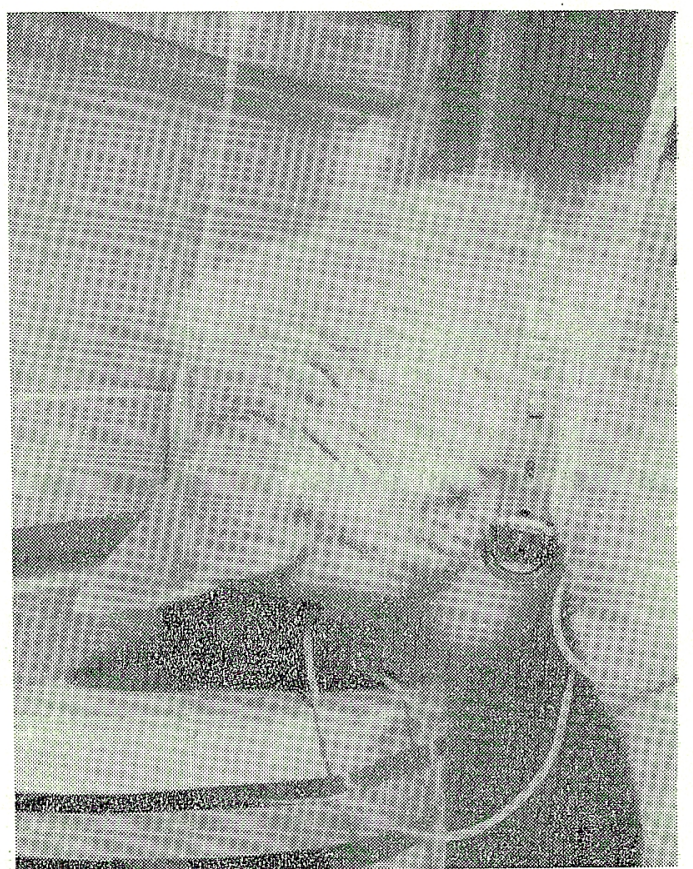

圈5 PCS時の姿營

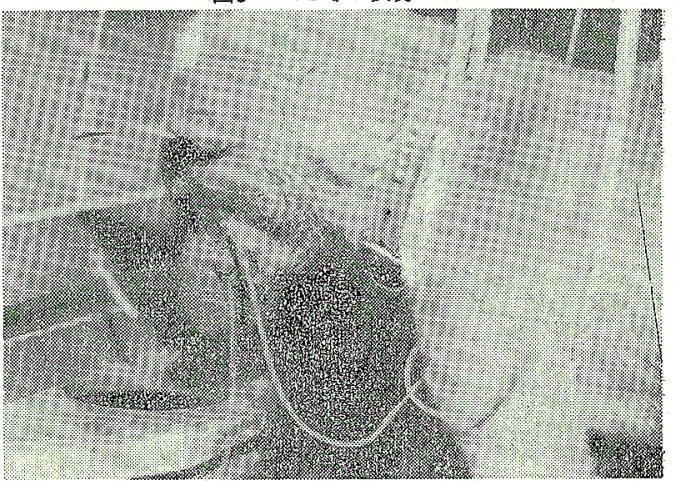

図6 NCS時の姿龆

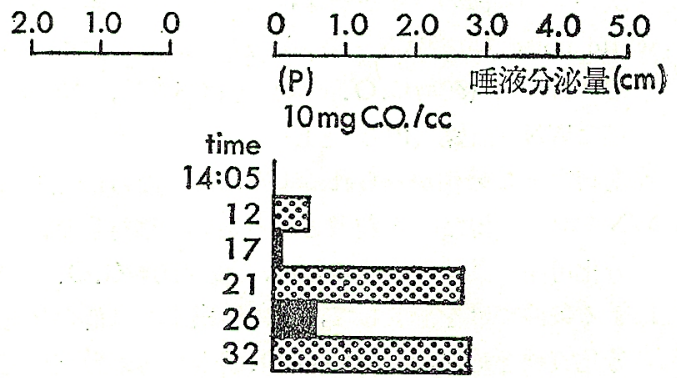

图7 10mg C.O. / ccによる初めての条件づけ

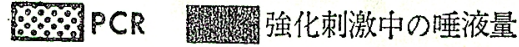


限りでなかった.これらの相違は呼吸曲線にもはっき り存在したが，それらについては後の項で説明する。

(IV) 閾値検查

上記の実験では30mg C.O.／ccを PGSとしてきたが 10mg G.O.／cck薄めても初めからよく反応してPGR が多く（図7）3系列でPGとの分化が完成した。

イヌの郻覚閾值が非常に低いことを考えて稀釈度を 一挙に高め $1 \times 10^{-1} \mathrm{mg}$ C.O. $/ \mathrm{cc}$ を用いたが，この場 合には成功しなかった。図 8 はその結果で，C.O.の 稀釈液と PG のいずれの CR も少晴で, PCS で最高

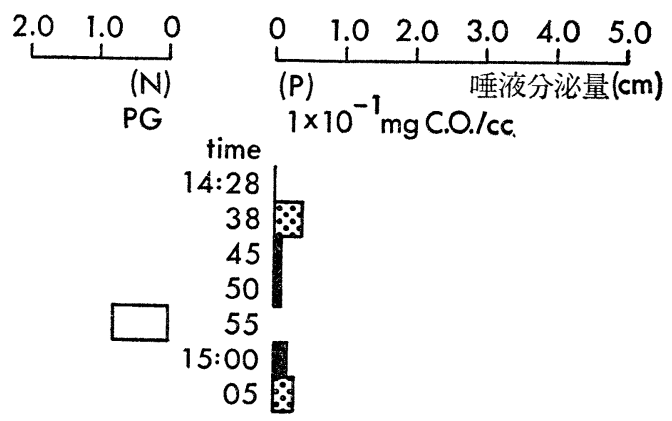

図 $81 \times 10^{-1} \mathrm{mg}$ C.O. / ccの初めての条件づけ

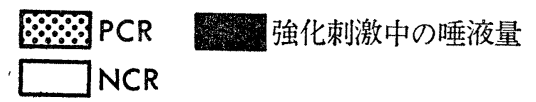

$0.4 \mathrm{~cm}$ ，NGS でむしろ0.8cmを示した．としてこの系 列中に，次第に匂に対する反応が低下する傾向がみら れた。

実験を元に戻して, 再び10mg C.O.／cc の濃度で強 化してから再度 $1 \times 10^{-1} \mathrm{mg}$ C.O. $/ \mathrm{cc}$ で分化形成実験

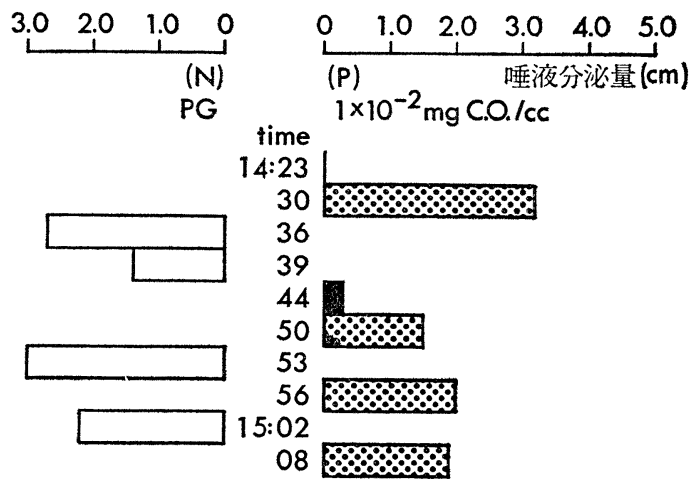

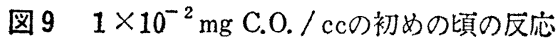

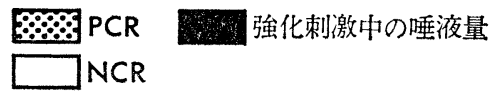

を行なったところ 4 系列で確実に分化し得た。この頃 より実験中，条件刺激のない時でも常時図6のような 姿勢をとることが多くなった。

次に上記の匂液を10倍に薄めた $1 \times 10^{-2} \mathrm{mg}$ C.O.／ ccの濃度では，6 系列続けて分化形成実験を行なった が分化は形成できず，初めの頃（図9）はPCSを与 え慨が与えられると次の NCS に対する反射に促進効 果が現われ，NCSを与えると次の PCR に抑制効果が 現われ分化が乱れた。そうして，NCSに対する睡液 量の方がむしろ次第に多くなった．6系列の終り頃に なると，条件反射唾液量は総体的に少なくなったが， 相互の抑制, 促進効果は多少継続していた.

止むなく $1 \times 10^{-1} \mathrm{mg} / \mathrm{cc}$ と $1 \times 10^{-2} \mathrm{mg} / \mathrm{cc}$ の間の 濃度 $\frac{1}{2} \times 10^{-1} \mathrm{mg}$ C.O. $/ \mathrm{cc}$ を使用して金験を行なった ところろ系列で分化可能となった（図10）。また $\frac{1}{3} \times$ 10-1 $\mathrm{mg}$ C.O. / cc では最初から分化を行った。このよ

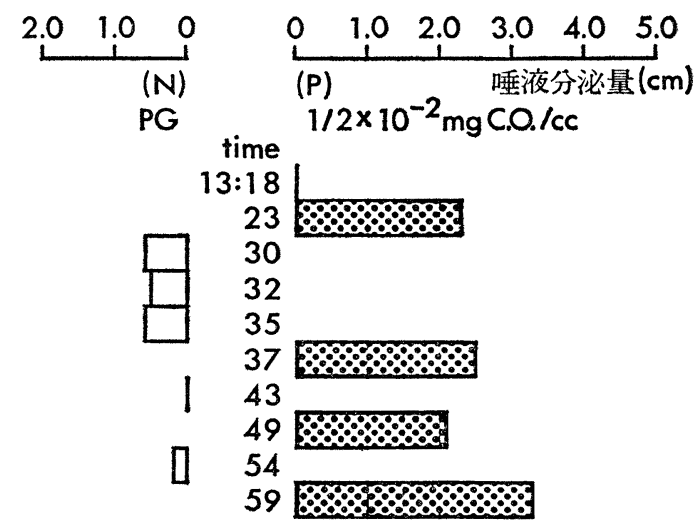

図10 $\frac{1}{2} \times 10^{-2} \mathrm{mg}$ C.O. / ccでの分化の形成

\section{$\because \because P C R \quad$ 強化刺激中の唾液量 NCR}

うな段階を経て再び $1 \times 10^{-2} \mathrm{mg}$ C.O. $/ \mathrm{cc}$ を用いて分 化実験を行なったところ，今回は初めから分化可能で あった. かくして $1 \times 10^{-1} \mathrm{mg}$ C.O. $/ \mathrm{cc}$ より 10-2mg G.O. / cc の濃度まで分化形成が進むのに17系列の実 験を要した。

濃度を更に稀釈して $1 \times 10^{-3} \mathrm{mg}$ G.O. $/ \mathrm{cc}_{\mathrm{n}}$ を用いて 分化実験を行うと11系列目に分化が形成された。

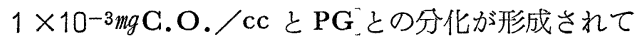

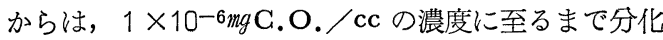
は非常に容易に形成された。すなわち $1 \times 10^{-4} \mathrm{mg}$ G.O. / cc では初めから P G との分化が可能であり, $1 \times 10^{-5} \mathrm{mg}$ C.O. $/ \mathrm{cc}$ は 1 系列後に分化が形成され, 
その後で $1 \times 10^{-6} \mathrm{mg}$ C.O. / cc の濃度でも初めから分 化が可能であった。図11は $1 \times 10^{-6} \mathrm{mg}$ C.O. $/ \mathrm{cc}$ を用 いた 2 系列目の結果である。これら高稀瀵の"G.O.で 分化が形成されたときの条件反射睡液量は同じ匂の

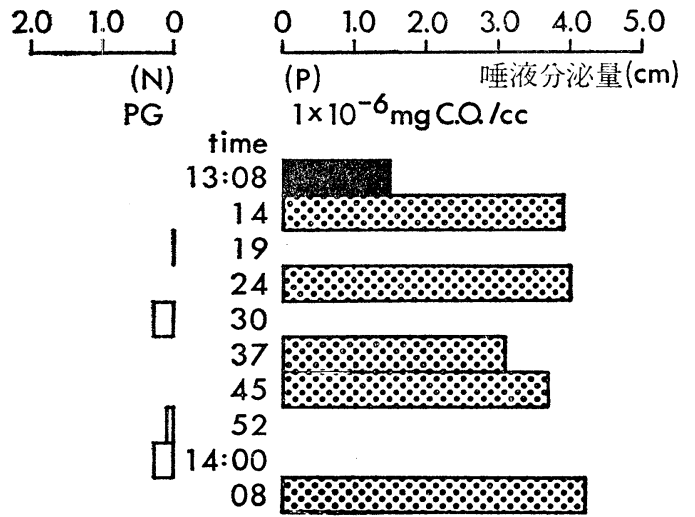

圈11 $1 \times 10^{6} \mathrm{mg}$ C.O. / ccの分化形成

\section{目 PCR 強化刺激中の唾液量 INCR}

30 mg / ccの場合と同じ，あるいはそれ以上で更に安定 していた。

次に $1 \times 10^{-8} \mathrm{mg}$ C.O. / cc で実験を行ったが 15 系列 の実験を重ねたにも拘らず分化不能であったため $1 \times$ 10-7mg C.O. / cc を用いて実験した。結果は図11 と同

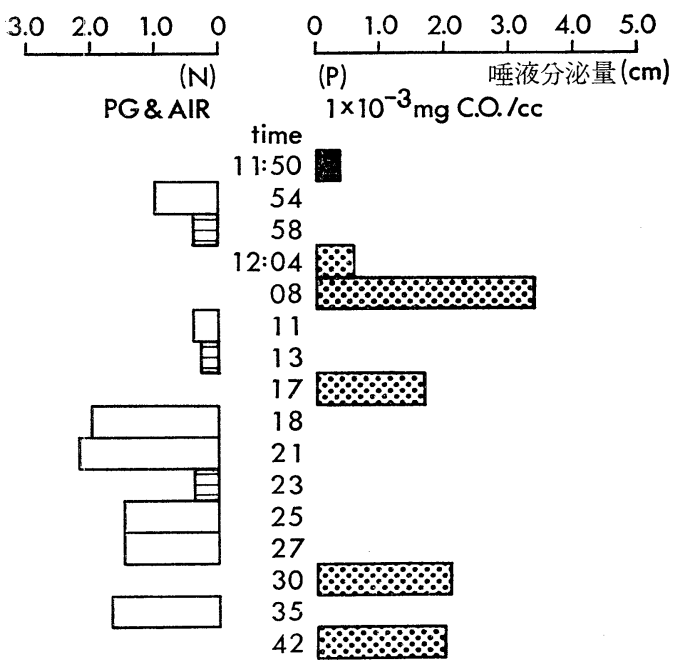

図12 N C S に空気の流れを用いた場合

䀤PCR 強化刺激中の唾液量
$\square$ NCR(PG) NCR(AIR)

様な結果を示した。しかし，その後の実験 でも 1 × 10-8mg C.O. / cc と P Gの分化は形成されなかった.

（V） NCSに空気の流れを加えた場合

$1 \times 10^{-3} \mathrm{mg}$ C.O. / cc と P G との分化形成以前の場合 抢よびこれらについて分化が形成された場合，更に分 化不能濃度 $1 \times 10^{-8} \mathrm{mg}$ C.O. / cc の場合に抢いて P G の他に空気をNCSに加えて実験を行なった。

図12は $1 \times 10^{-3} \mathrm{mg} \mathrm{C} . \mathrm{O} . / \mathrm{cc}$ の分化形成以前の結果 であるが,この系の中，後半になるにつれ，イヌがP $\mathrm{G}$ およびC.O.稀釈液を $\mathrm{PCS}$ として受容し，空気だけ の条件刺激を NCS として受容したことがわかる。す なわち P Gの匂の有無で分化しているのである.

この漕度の分化形成後に再び空気を NCS に加えて

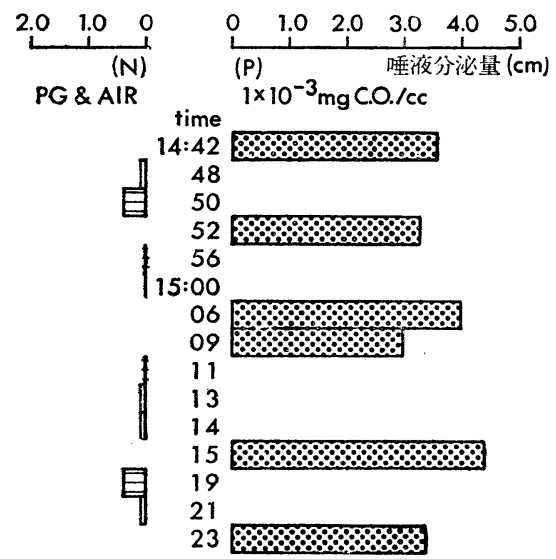

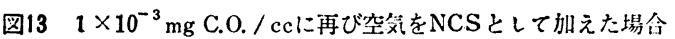
\%PCR $\square$ NCR(AIR) $\square$ NCR(PG)

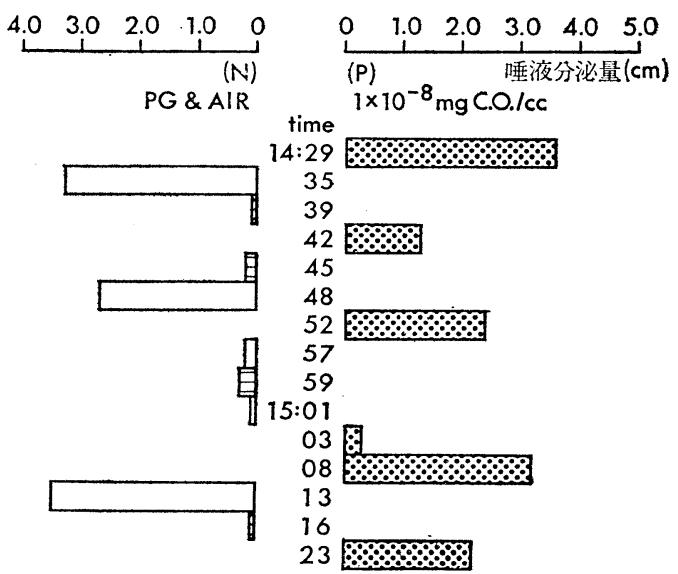

图14識別不能時にNCSに空父をを加えた場合 \%3PCR $\square$ NCR(AIR) $\square$ NCR(PG) 


$$
\text { NCS }
$$

図15 P C S と N S 時の呼吸変化

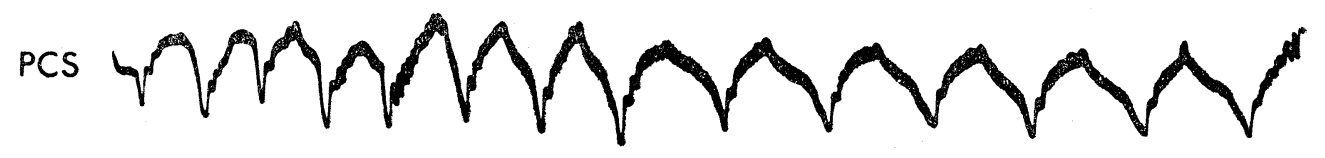

NCs

PCS

NCs

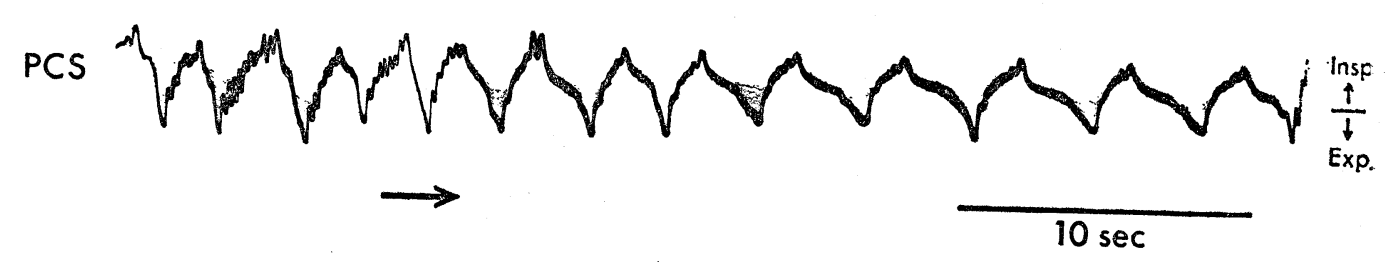

図16 匂識別不能時の呼吸変化 
実験を行うと，図13 のごとく今回は明らかにC.O.を かぎ出しており，空気および P Gだけの刺激に対する 睡液量注ほとんど零に近い，そして今回は，空気だけ の刺激の場合, 刺激後匂出口ょり鼻を遠くへ離してし まい,リラックスした状態であった。

分化不能濃度 $1 \times 10^{-8} \mathrm{mg}$ C.O. $/ \mathrm{cc}$ で空気をNGSに 加える之，やはり P Gの匂の有無というパターンで分 けてしまった（図14）。

（VI）句条件反射と呼吸の変化

上記の実験と併行して匂刺激に対する呼吸曲線を記 録し，条件反射と比較したところ PCS と NGS とに対

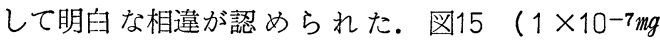
C.O. $/ \mathrm{cc})$, 図16 $\left(1 \times 10^{-8} \mathrm{mg} \mathrm{C} . \mathrm{O} . / \mathrm{cc}\right)$ にその 例を示す，呼吸数は天候などに左右されたが，実験箱 内では平均毎分25回（18〜31）で，PCS，NCS にか かわらず刺激を与えるとむしろその数は減少した。し かし，その減少の仕方に差があり，図15にも示すよう にNCS の方が減少率は高く，PCS では平均27\% NCS では平均35\%減少した。

これに対して刺激中の呼吸の梁さはPCS の方がや や大きかった，最も顕著な差が現われたのは，匂刺激 を与えた場合の最初の呼吸曲線であった。一般に $\mathrm{PC}$ SではNCSに比較して，吸気相が急勾配であり，また PCSでは，その前の呼吸が呼気相であっても直ちに吸 気相に移ってしまうという特徴がみられた。

しかし分化不能の場合には上記の関係は認められず 図16にみられるように上記の関係が乱れ，相互のパタ 一ンが入れ変ったり, 中間型が現われた。

このように，包刺激に対する呼吸曲線の変化を記録 すれば，句条件反射の成立，または分化形成の指標と して棰液量測定と同様充分に役立つことが判明した。

\section{考察}

本実験の初期に，嗅覚的動物といわれるイヌの旬条 件反射形成が困難であった理由として次のようなこと が考元られる。すなわち，あらゆる求心性信号は複合 的，総合的なゲシュタルトとして受容され，匂刺激に 対して特に敏感であるとしても，決してそれだけが単 独にはたらいているわけではない，その意味では，実 験環境はイ邓にとってきわめて異質の刺激状況々考元 られる。

更に clove oil という物質は一般にイヌの生存環境 には見出されないものである。そのために，強い探求 反射が条件反射や分化の形成にとって外制止としては
たらいていたものと思われる。こういう事情は，あら 方条件反射実験の初期にみられる傾向である。

次に，匂刺激の場合には，条件反射実験によく使わ れる光, 音, 機械的刺激などと比較して特殊な条件が 少なくない，例えば，脱臭という操作を必要とするの もその一つである．また刺激物質が受容器に吸着する という問題も他の実験には存在しない. 特に低濃度の 場合には，能動的な行動がなくては包を受容すること ができない．また，残臭がまったくないとはいえない から，すべて受動的に刺激を受けられる光，音等の刺 激とは状況が全く違っている。それは動物が努力して 刺激を受容する場合とそうでない場合に大ざっぱに区 分できるから，嗅覚の場合，匂を受容するということ と，匂をかぎ出すということは異なるという考えに関 連している (Moultonら, 1960)。

それ故, 匂物質がイヌの受容器に有効にはたらくた めには特別な工夫を必要とする。しかしイヌの姿勢を 匂流出口に対して固定するょうに拘束すれば Becker

（1957）らの実験以上に強い逃避反射が現われ実験を 妨害することになる．また実験室に充満するような包 刺激を与えれば，脱臭のための困難を覚悟しなければ ならない。

この実験で，音，音十匂，匂を条件刺激とした 3 段 階の実験を経由させたのは，イヌが匂物質を有効に受 けとめるように句受容器を位置させるための必要な操 作であった。しかし，このような操作を経ても，イヌ の条件反射形成過程にはかなりの個体差がみられた。

Becker（1957）らが一カ所より匂を吹き出し，そこ にイヌの注意を向けようとしたが失敗し，その方法を 中止してしまったように，Dog 2 は音条件反射で $500 \mathrm{c} / \mathrm{sec}$ に条件づき，100c/sec しか違わない音を も分化し得たが，遂に句条件反射を得ることができな かった。

当然のことながら，この種の実験では実験環境が単 純であるほどすぐれている．特に匂刺激の場合は，匂 を有効に受容するために複雑な経過を必要とする。従 って匂流出に伴なう他の情報源が条件刺激として作用 する可能性が大なることに特に注意を必要とした。こ の意味で実験室内にイヌとともに人間が介在した Bceker らの実験が支障を来したのは当然であろう。

著者の方法では，実験者はイヌと二重の壁によって 隔絶されており，与える刺激について実験者が知って いてもいなくても，その影響がイヌに及ぶことはな 
い. 実験者が NCS を与えていると思いながら，実は PCSを与えた場合も，唾液は多量に分泌された。

また，包刺激では当該刺激のみ純粋に与えることは 困難で, 空気流や溶媒臭がともに加えられる場合が多 い点で特別の配慮が必要になる．特に，閾值測定では PGS として用いる物質が稀薄な場合は，PCSが受容さ れずに溶媒臭に対して強化が行われたり，行われなか ったりという混乱がおこる．図８にみられる結果もそ のためと思われる。

匂刺激法としては, Moulton (1960) らおよび Becker（1962）らの研究者は匂物質のある場所まで イヌが歩いて行き，そこで包をかぐという方法を用い た。それにもかかわらず嗅覚間值は人間と大差なかっ たという。

しかし, F.N.Jones (1955) の研究では, 容器に 入れた匂をかぎ゙させる方法の方が，匂を吹きつける 場合より閾值が低かったという，その理由は，吹きつ けの場合量的にあらかじめ定めた量しか与えられない が，匂かぎ出し法では匂物質を容器に入れたまま提出 するため, 空気中の量が比較的多くなるためであろ う, と述へている. 更に, 匂かぎ出し法では, 実際に イヌが吸いこんだ空気中に含まれている匂物質の量を 決定することが困難である。

条件づけの期間も検討する必要がある.

Becker らは最初にたてた実験計画の期間内で結論し ているが，このような方法では本実験で 1 力月半も要 した $1 \times 10^{-2} m g \mathrm{C} . \mathrm{O} . / \mathrm{cc}$ の場合などは識別不能濃度 之結論される可能性がある.嗅覚研究者の閾值測定結 果に大きな差があるのは，以上のような事情によると ころも少なくないであろう。しかし，それだけではな く閾值というもの自体に問題があることも検討する必 要があるであろう。すなわち, 生体は単なる刺激を受 けとめる反映体ではない，刺激もその生存条件と結び ついて受けとられる。その刺激を受容する必要性, 分 化する必要性に応じてそれぞれの能力に差がついてく る. 従って, 実験方法, 実験のくり返し回数によって 闇俌といわれるものに差がみられるのは当然であろ う.

人間が識別し得る濃度の限界は C.O.では $1 \times 10^{-1}$ $m g / \mathrm{cc}$ で，この濃度まではイ邓も比較的容易に分化し 得るが, これも Moulton (1960) らのいうょうに, イヌの溴覚感受性が生来すぐれているということより も, 生活に密着した必要性により, 卓越した能力を身
につけたと考えるべきであろう。

本実験で験者は，P G と識別不能の C.O. 稀釈液の 分化実験にさらに質的に異なる空気の流れをNCS と して加えてみた。その結果，質的に大分離れたものが 加わった場合，イヌは類似した刺激を同一のものとし て受容してしまった。この点で Kalmus（1957）の両 実験に存在した実験状況の相違之関連した問題が生じ ている。すなわち，この実駼結果は，一卵性双生児識 別実験のうち双生児の一方のハンカチを探して持って くる実験結果と同し意味を持っている. Kalmus は一 畉性双生児をむ識別し得た追跡実験に比して，ハンカ チを探す実験では一時に一つの匂にしか直面できない が，追跡実験では同時に 2 種の臭跡に直面できるとい う状況に結果の相違の原因を求めている。追跡実験の 場合には，双生児二人の足跡だけが残されており，他 の人間の足跡はない。すなわちこの場合には，質的に かけ離れた比較臭が存在していない. Kalmus は指摘 していないが，この点も両実験に差を生じた大きな原 因となっていることは, 本実験結果より充分推測でき る.

$1 \times 10^{-2} m g$ C.O. $/ \mathrm{cc}$ および。 $1 \times 10^{-3} m g$ C.O. $/ \mathrm{cc}$ と $\mathrm{PG}$ との分化形成には長期間を要したが, 一旦 $1 \times$ 10-3mg C.O. / ccの包識別が完成すると $1 \times 10^{-6} \mathrm{mg}$ C. O. $/ \mathrm{cc}$ まで非常にスムースに分化が進んだ．これは 分化実験の一般法則と一致するだけでなく, 匂識別基 点が, ある程度量的なものから質的なものに移ったよ うに推定される。

匂の識別に打いて，大きい此重をしぬるものは何 か?.特にイヌの包による識別に打いては Kalmusは 質的なものより量的なものであろうと述へているが Neuhaus は物質混合パターンによるものであると結 論している。しかし，これらの報告はとれぞれの実験 方法, 実験回数等が異なっており, 前にも述べたよう に，他にも種々の錯綜した因子を内蔵した結果よりひ き出されたものである.本実験の結果をあわせ考光る とき, 質, 量, 混合パターンの中の一つだけが包識別 において重きをしめていると断定することはできな い。むしそそれぞれの因子が流動的であると思われ

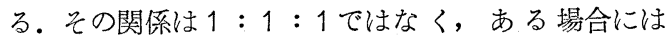
$100 ： 1 ： 1$, またある場合には $3: 10 ： 100$ というよ うに，その状況に応じて動物の都合のよい状態の因子 あるいはその複合したものによって区別して生活して いるのであろう。 


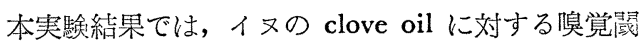
值は人間より100万倍も低い。これは，Neuhausの 結果と合うものである. 更に, 匂刺激時に呼吸曲線変 化を記録したが，呼吸変化によってもイヌが包を識別 しているかどうか判明する。

イヌが当該臭を選択した確率を統計的に処理し，偶 発率を闘值とする方法よりも，需液量測定とともに呼 吸変化をもみた本実験の方が，方法的により確実で市 ると考元られる。

\section{要 約}

唾液条件反射を用いてイヌの搝覚を研究した。

1 まず包による唾液条件反射を成立させる方法を述 心゙た。

2 Propylen Glycol に溶かした Clove Oilに対す るイヌの溴覚闖值は $1 \times 10^{-7} \mathrm{mg} / \mathrm{cc}$ で，人間の闘值よ

り 100万倍も低いことが明らかにされた。

3 稀鄱率を高くする場合, 陽性条件刺激である Clove Oil 稀釈液の匂と陰性条件刺激であるPropylen Glycol の匂は非常に類似し, イヌの睡液分泌反射が乱 れてきた。 その時点で, さらにそれらと質的にかけ離 れている刺激（空気流）を陰性条件刺激として加える と, イミは空気流を陰性条件刺激として受容し, Clove Oil 稀釈液のみならず Propylen Glycol をも陽性 条件刺澈として受容した。

4 匂を識別しているかどうかという客観的基隼とし て, 唾液量測定の他に呼吸曲線記録の有用性が見出さ れた。

5 匂識別の因子として量, 質, 混合パターンなどが あるが，匂を識別する際の環境の錯綜した要素のうえ にたって，最も利用しやすいものによってイヌは包を 識別しているょうに孝えられる。その意味で, 包の䈅 值というものも状況に応じて異ってくることが推定さ れる。

おわりと本研究の䐚指導, 御校閲をいただいた群馬大学高 木貞敬教誩に深く感謝いたします。また終始適切な御助言, 御校閲, 御鞭遅をいただいた法政大学千葉康則教授に篤く御 礼申し上げます。さらに实験助手を勤めてくれた小林和校筫

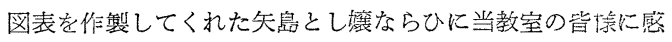
謝の意を表します。

$$
\text { 文献 }
$$

1) Allen, W.F. : Olfactory and trigeminal conditioned reflexes in dogs.
Am. J. physiol., $118:$ 532 540, 1937.

2) Allen, W.F.

Am. J. physiol., 121 : 657 668, 1938.

3) Allen, W.F.

Am.J. physiol., $128: 754 \sim 771,1940$.

4) Allen, W.F.

Am.J. physiol., 132: 81 92, 1941.

5) Ashton, E.H., Eayrs, J.T. and Moulton, D.G. : Olfactory acuity in the dog.

Nature, $179:$ 1069 1070, 1957.

6) Becker, R.F., Markee, J.E. and King, J.E. Studies on olfactory acuity in dogs.

( I ) Discriminatory behaviour in problem box situations. Brit. J.Animal Behaviour,

$$
5: \text { 94 103, } 1957
$$

7) Becker, R.F., King, J.E. and_Markee, J.E.

Studies on olfactory discrimination in dogs.

(II) Discriminatory behaviour in a free enviroment.

J.Comp. physiol. psychol., $55:$ 773 780, 1962.

8 ) 深見 安: 条件反射形成（分化形成）に対する嗅 覚の影響

科学, 31 (2) : 90 91, 1961.

9) Jones, F.N. : The reliability of olfactory thresholds obtained by sniffing.

Am. J. psychol., $68:$ 289 290, 1955.

10) Jones, F.N. : A comparison of the methods of olfactory stimulation : Blasting vs. sniffing. Am. J. psychol., 68:486 488, 1955.

11) Kalmus, H. : The discrimination by the nose of the dog of individual human odours in particular of the odours of twins.

Brit. J. Animal Behaviour, 3 : 25 31, 1955.

12) Katz, R.A., Sutherland, G.F. and Brown, C.C. : Measuremet of Salivation., Methods in psychophysiology, 173 191, 1967., The Williams \& Wilkins Company.

13) Moncriff, R.W. : Olfactory adaptation and odour intensity., Am.J. psychol., $70: 1 \sim 20,1957$.

14) Moulton, D.G., Ashton, E.H. and Eayrs. J.T. : Studies in olfactory acuity. 4. Relative 
detectability of $\mathrm{n}$-aliphatic acid by the dog. Animal Behaviour, $8: 117 \sim 128,1960$.

15) Neuhaus, W. : Über die Riechschärfe des Hundes für Fettsäuren.

Z. Vergl.physiol., $35:$ 527 552, 1953.

16) Neuhaus, W. : Die Unterscheidung von Duftquantitation bei Menschen und Hund nach Versuchen mit Buttersäure.

Z. Vergl. physiol., $37:$ 234 252, 1955.

17) Neuhaus, W.:Die Riechschwelle von Duftgemischen beim Hund und ihr Verhaltnis zu den Schwellen unvermischter Duftstoffe.
Z. Vergl. physiol., $38: 238 \sim 258,1956$.

18) Neuhaus, W. : Die Unterscheidungsfähigkeit des Hundes für Duftgemische.

Z. Vergl. physiol., 39:25 43, 1956.

19) Neuhaus, W. : Wahrnehmungsschwelle und Erkennungsschwelle beim Riechen des Hundes im Vergleich zu den Riechwahrnehmungen des Menschen.

Z. Vergl. physiol. $34: 624 \sim 633,1957$.

20) Uchida, T. : Fatty acids and the olfactory sense of dogs.

Proc. Jap. Acad. $32:$ 753 758, 1956. 


\section{OLFACTORY STUDIES IN THE DOG \\ HIROSHI KAISE}

\section{Department of physiology, Gunma University School of Medicine}

(Director:prof. Sadayuki F.Takagi)

Employing the classical conditioned reflex as an experimental method, the author intended to clarify the olfactory acuity of a dog.

As a test odor, clove oil, which is a non-meaningfull smell for dogs, was used. It was diluted by propylen glycol into various concentrations.

At first, a method to obtain salivatory conditioned reflex by clove oil odor was establ ished. By this method the following results were obtained:

1) Olfactory threshold of a dog for clove oil was $10^{-7} \mathrm{mg} / \mathrm{cc}$. This is million times lower than the olfactory threshold of man.

2 ) The diluted solution of clove oil and propylen glycol itself were presented to a dog for olfactory discrimination. When the clove oil was highly diluted, the conditioned salivatory reflex of the dog became very irregular to the two solutions. But when a third and very dissimilar odor was presented together with the diluted clove oil or propylen glycol, the dog showed salivation regularly to the clove oil solution and the propylen glycol itself, but not to the dissimilar odor.

3 ) Beside the measurement of salivation, recording of respiration was found to be very useful for the study of the discriminative ability.

4 ) It is conjectured that there are mainly three factors involved in the olfactory discriminative processes of a dog, that is, quantity, quality and odor patterns formed by combinations of odor substances.

It is conceivable that a dog discriminates odors by taking advantage of the most useful factor among the above three.

In some cases, a dog may make use of two or more factors in combination.

Consequently, it may be said that the olfactory threshold of a dog changes depending upon various circumstances. 